\title{
Heme Protein
}

National Cancer Institute

\section{Source}

National Cancer Institute. Heme Protein. NCI Thesaurus. Code C16675.

Proteins that contain a metal-containing cofactor that consists of an iron atom

contained in the center of a large heterocyclic organic ring called a porphyrin. One of the main functions of heme proteins is the retention of molecular oxygen to deliver it for enzymatic reactions. As a result, many heme-containing enzymes are located in the mitochondrion. 